\title{
Monitoring antibiotics and inflammatory markers in human blood: Impact in choice of antibiotic therapy and used methods
}

\author{
Anna N. Berlina, Anatoly V. Zherdev and Boris B. Dzantiev,* \\ 1 A.N. Bach Institute of Biochemistry, Research Center of Biotechnology of the Russian Academy of Sciences, \\ Leninsky prospect 33, Moscow 119071, Russia; berlina.anna@gmail.com; zherdev@inbi.ras.ru; \\ dzantiev@inbi.ras.ru \\ * Correspondence: dzantiev@inbi.ras.ru; Tel.: +7-495-954-3142 (B.B.D.)
}

\begin{abstract}
In the modern world, the problem of antibiotic therapy is acute. Despite the diversity of existing antibiotic drugs, their efficacy decreases as new, resistant forms of pathogenic microorganisms emerge. It is extremely difficult to control such processes and even more difficult to treat severe bacterial infections. In such situations, an individual approach to each patient is required and physicians need parameters to estimate the efficacy of antibiotic therapy. This review discusses the significance of monitoring the content of antibiotics in the blood for this purpose, in combination with the content of inflammatory markers, such as C-reactive protein and procalcitonin. The basic principles of antibiotic therapy, and factors in the resistance of microorganisms to antibiotics, are examined. Approaches to assess the efficacy of antibiotic therapy, as well as methods to detect antibiotics and inflammatory markers in the blood of patients, and comparative assessment of their capabilities and limitations, are described.
\end{abstract}

Keywords: individual therapy; metabolism of antibiotics; dosage choice; inflammation; biomarkers

\section{Use of antibiotic drugs in treatment of bacterial infections}

Timely antibiotic therapy is an effective method for treatment of most bacterial infections, because it eliminates the causes of the inflammatory process. Infections of mild to moderate severity can be cured with timely and proper treatment. In case of severe medical conditions, especially those accompanied by sepsis, every hour of delay in starting therapy brings the patient closer to death, due to an increasing number of organ dysfunctions [1,2]. Therefore, a number of studies demonstrate that antibiotic therapy should be started as early as possible [3,4]. Rational antibiotic therapy is based on several important principles. The microbiological principle regards the knowledge and understanding of the causative agent of the disease. For this purpose, microbiological methods are used, i.e., plating onto a culture medium [5]. After confirming the presence of bacterial growth, the sensitivity of the detected pathogen to the main classes of antibiotic drugs is determined [6], and the antibiotics that best penetrate the affected tissues are selected.

The clinical principle means the use of antibiotics according to the patient's condition. If the severity of the patient's condition compels the use of antibiotics before the causative agent is identified, broad-spectrum antibiotics are used (empirical antibiotic therapy) [7]. If, after $72 \mathrm{~h}$, the patient's status does not improve, then the drug is changed to a more efficient one, and the reason the initial treatment did not have any effect is sought.

The pharmacological principle means that the dosage and duration of the drug's application should be commensurate to the severity of the disease in a particular situation. Having information about the presence of concomitant diseases and the drugs taken simultaneously is important, since it is necessary to take the possibility of their synergism or antagonism into account $[8,9]$.

The epidemiological principle means an adherence to the treatment regimen during a prolonged drug's application. The choice of drug should take into account the presence of resistant strains in a 
particular clinical department, hospital, or region [10]. The duration of application depends on the antibiotic's class, its characteristics and the duration of its circulation in the blood, as well as on the severity of the disease. The course of antibiotic therapy should not be interrupted and started again after a day or two, because this leads to the development of bacterial resistance to antibiotics, leading to the transition of the infectious process into a chronic, sluggish form which is very difficult to treat. On average, the duration of treatment is 5-10 days; if necessary, the course is prolonged, while the biochemical parameters of the blood and general state of the patient are monitored.

The pharmaceutical principle means compliance with expiration dates and specified storage conditions of drugs. The current classification of antibiotic chemotherapeutic drugs includes eleven classes, distinguished on the basis of chemical structure [11]. For antibiotic therapy, antibiotic drugs are necessary. But, given the wide variety of available broad-spectrum antibiotics, in $15 \%-30 \%$ of cases patients receive inadequate empirical therapy [12, 13]. In the latest (2017) guide for the management of patients with sepsis or septic shock [14], the first principle of antibiotic therapy is the administration of antibiotics as early as possible, i.e., within the first hour after diagnosis. The second principle is empirical antibiotic therapy - the prescription of broad-spectrum drugs in combination with drugs that have antiviral (if necessary) and antifungal activity, to eliminate possible pathogens of a non-bacterial nature. An important factor in this treatment is how fully the drug covers the suspected group of pathogens. One of the factors influencing the prescription of empirical antibiotic therapy is the number of neutrophils - with neutropenia, patients are particularly susceptible to superinfection caused by gram-negative bacteria (Stenotrophomonas maltophilia, Acinetobacter baumannii, Pseudomonas aeruginosa) and fungi of genus Candida [15].

\section{Use of data on pharmacokinetics of drugs and resistance of microorganisms in treatment of bacterial infections}

One important parameter when choosing a drug is its pharmacokinetics - the entirety of the processes the drug undergoes from the moment it enters the body, through its absorption, metabolism and excretion. The intake, circulation, and modification of the active substance in the human body also depends on the means of administration. In modern clinics and hospitals, preference is given to drugs that can be administered parenterally (especially intravenously or intramuscularly), since this method of administration ensures the greatest bioavailability of the drug, accelerates its entry into the bloodstream and reduces the risk of presystemic biotransformation, or biotransformation of the drug during its "first-pass" through the liver, before entering systemic circulation [16]. Drugs are administered quickly and quickly begin to act. If the blood vessels are not accessible (in case of shock or other reasons), $\beta$-lactams can be administered intramuscularly. AbdulAziz et al. (2016) demonstrated that beta-lactams have a greater efficacy when administered as intravenous drips in comparison with their administration in the form of tablets and capsules. Among the drugs of choice are cefepime, meropenem, and piperacillin (tazobactam) [16] - betalactam antibiotics of the subgroups of cephalosporins and carbapenems. When administered intravenously, these drugs quickly (from $30 \mathrm{~min}$ to $2 \mathrm{~h}$ ) reach a maximum concentration in the blood, and are distributed to various organs and tissues. The main antibiotics used in the treatment of severe bacterial infections in the last five years, and their pharmacokinetic characteristics and compatibility during combination therapy are shown in Table 1 . Nimmich et al. also showed that the use of betalactams in combination with antibiotics of another group increases the survival of patients with severe forms of disease [17]. Unlike the first studies, the main beta-lactam antibiotics in the studied groups of patients were third-generation cephalosporins (cefixime, cefotaxime, ceftriaxone, ceftazidime, cefoperazone, ceftibuten, etc.). 
Table 1. Data on modern drugs used in severe clinical cases of bacterial infection.

\begin{tabular}{|c|c|c|}
\hline Antibiotic & Pharmacokinetic indicators (beta-lactams) & Ref. \\
\hline Meropenem & $\begin{array}{c}\text { Cmax is reached within } 30 \mathrm{~min} \text {, binding to blood proteins is less than } 2 \% \\
\text { (leading rapid excretion and requiring administration every } 8 \mathrm{~h} \text { ). Penetrates } \\
\text { into most tissues and body fluids, including the cerebrospinal fluid. Synergism } \\
\text { with many groups of antibiotics. }\end{array}$ & [16] \\
\hline Ceftriaxone & $\begin{array}{c}\text { Cmax is achieved within } 2-3 \mathrm{~h} \text {, binding to plasma proteins is } 85 \%, \mathrm{~T} 1 / 2 \text { is } 5.8- \\
8.7 \mathrm{~h} \text {. Bioavailability is } 100 \% \text { (IM), penetrates into the cerebrospinal fluid. } \\
\text { Synergism with aminoglycosides. }\end{array}$ & {$[17]$} \\
\hline Cefepim & $\begin{array}{c}\text { Cmax is achieved within } 1.5 \mathrm{~h} \text {, binding to plasma proteins is } 20 \%, \mathrm{~T} 1 / 2 \mathrm{is} 2 \mathrm{~h} \text {. } \\
\text { Bioavailability is } 100 \% \text { (IM), penetrates into the cerebrospinal fluid. Increases } \\
\text { nephro- and ototoxicity of aminoglycosides. }\end{array}$ & [15] \\
\hline
\end{tabular}

A great difficulty in antibiotic therapy lies in the adaptive characteristics of microorganisms developed during evolution. Since the discovery of antibiotics of the penicillin group ( $\beta$-lactams), gram-negative microorganisms have acquired the ability to produce $\beta$-lactamase, an enzyme that destroys the beta-lactam cycle in the structure of the antibiotic [18]. Thus, over time, and especially when the regimen of treatment for bacterial infections is not observed, the therapeutic concentration of the drug decreases, and the pathogen in contact with this drug becomes resistant to this antibiotic and is released into the environment, infecting another patient. The selection of pathogens takes place. In addition to the main causative agent of the disease, other gram-negative bacteria that comprise the normal microflora of the human's body trigger the mechanisms of production of this enzyme, and then saprophytes or opportunistic microorganisms can lead to superinfection [19, 20]. In pathogens, a specific gene (or several genes) is responsible for the development of antibiotic immunity [21]. This property results in a wide spread of the resistance gene through plasmids, therefore, the efficacy of therapy is reduced even if the last-resort drug, colistin, is used [22, 23]. In addition to the spread of plasmids containing antibiotic resistance genes, there are other factors of pathogen resistance, such as a change in membrane permeability, when a drug cannot be transported across the compressed membrane. Bacteria can also produce enzymes that modify the drug's molecules, which, ultimately, also leads to its inefficiency relative to the causative agent of bacterial infections. Such enzymes include beta-lactamase. In addition to the production of this enzyme, a bacterial cell can modify receptors (targets) of $\beta$-lactam antibiotics on its surface, which also contributes to further pathogen immunity to the administered drug [24]. Bacteria are also capable of excreting an antibiotic drug after it enters the body, via the use of an efflux pump. The described mechanisms of microorganism resistance are presented in Figure 1.

Severe clinical cases are situations in which the pathogen is multiresistant to several antibiotic drugs, or entire groups at the same time [25, 26]. Among them, strains of E. coli that have plasmids with genes providing resistance to most antibiotics have the opportunity to spread in human populations. The presence of multi-resistant strains in hospitals is fraught with them wide-spreading in various ways (alimentary, airborne and others), since these pathogens are representatives of the natural microflora and are able to multiply both in the gastrointestinal tract and on the wound surface, in case of injuries or any interventions. Often, such microorganisms are conditionally placed into a separate group and the hospital-acquired infectious processes caused by them are called nosocomial infections $[27,28]$. Such cases are very difficult for antibiotic therapy. Despite reaching the maximum concentration of antibiotics in blood plasma, therapy often turns out to be completely inefficient. On the one hand, this is due to the kinetics of the drug, meaning the antibiotics are absorbed with the formation of a saturating maximum possible concentration in the plasma, and on the other hand, this is due to the triggering of protection mechanisms by the pathogen in the infectious focus. Thus, the drug goes through all stages of modification and excretion without affecting the pathogen. A study by Lee et al. [15] demonstrated that antibiotic resistance is formed quite rapidly in case of infection caused by gram-negative microorganisms. For instance, Stenotrophomonas maltophilia, Acinetobacter baumannii, Pseudomonas aeruginosa and Enterobacteriaceae 
strains that appear in many studies are nosocomial infection strains (pneumonia, catheter sepsis); they enter the patient's body before treatment with carbopenem, resulting in the production of $\beta$ lactamases [29-31].

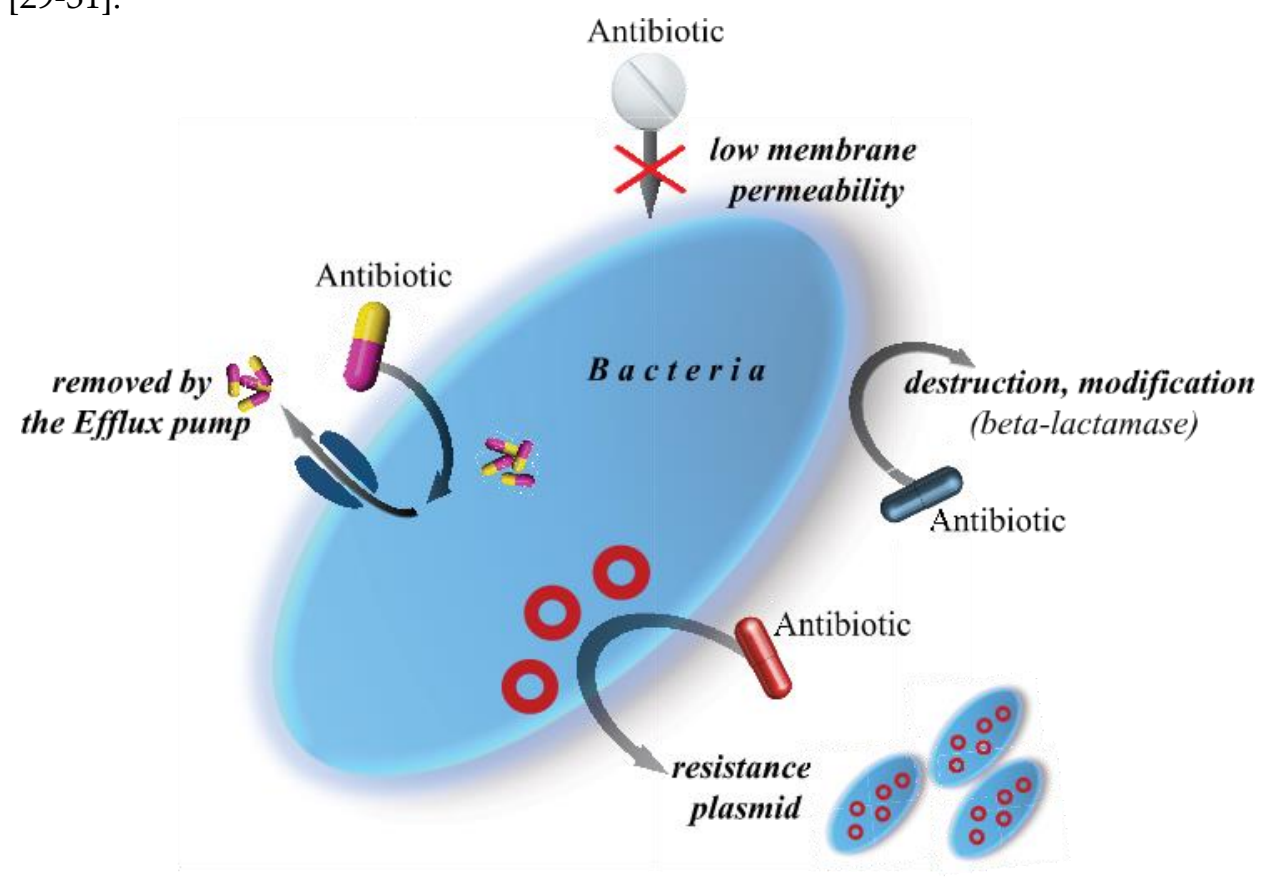

Figure 1. Mechanisms of microorganism's protection from the action of antibiotic [21]

Given the studies demonstrating the lack of efficacy of monotherapy, various methods of combining antibiotic agents [32] with the use of complex antibiotics with $\beta$-lactamase inhibitors are considered. Table 2 presents combinations of drugs with known positive results that are used in modern practice. In some cases, antibiotics are combined according to the principle of one of the cidal group, one or more of the statics, for example, beta-lactams and tetracyclines, betalactams and aminoglycosides [16]. This is due to their mechanism of action, the localization of the pathogen (extracellular and intracellular), as well as the cross-resistance of the pathogen if superinfection is suspected.

Table 1. Some combinations of antibiotics and inhibitors of bacterial enzymes.

\begin{tabular}{|c|c|c|c|}
\hline Antibiotic & Combination & Target & Ref. \\
\hline Rifampicin & $\begin{array}{l}\text { Up to three new drugs } \\
\text { TMC207, PA824, } \\
\text { OPC67683/Isoniazid, } \\
\text { Ethambutol can be } \\
\text { added }\end{array}$ & $\begin{array}{l}\text { Mycobacteria tuberculosis, including } \\
\text { resistant forms }\end{array}$ & [32] \\
\hline Sulfamethoxazole & Trimethoprim & $\begin{array}{c}\text { Gram-negative, gram-positive } \\
\text { bacteria resistant to sulfonamides }\end{array}$ & [33] \\
\hline Colistin & Another antibiotic & Gram-negative bacteria & [34] \\
\hline Penicillin & $\begin{array}{l}\text { B-Lactamase inhibitors } \\
\text { (Clavulanic acid) }\end{array}$ & $\begin{array}{c}\text { Gram-negative, gram-positive } \\
\text { bacteria resistant to beta lactams }\end{array}$ & [35] \\
\hline Beta lactams & $\begin{array}{c}\text { Teichoic acid synthesis } \\
\text { inhibitor } \\
\text { (Tunicamycin) }\end{array}$ & Staphylococcus aureus & [36] \\
\hline
\end{tabular}




\section{Markers of inflammatory processes and choice of bacterial infections are promising in terms of efficacy of treatment}

Inflammation is a normal reaction of the human immune system to the intrusion of infectious agents of a viral, fungal or bacterial nature. The mechanism of local or general inflammatory reactions are based on interactions of cellular receptors with antigens and inflammatory mediators [37]. The generalization of the local infectious process is called sepsis.

Sepsis is one of the main causes of death in patients after ineffective and untimely antibiotic therapy, fulminant infections, superinfection, inadequate diagnosis of the patient's condition, risky surgeries performed in violation of asepsis standards, or the appearance and spreading of a wound infection [2]. The generalization of the process, resulting in the disruption of the biochemical functions of vital organs and the appearance of local foci of inflammation, leads ultimately to the inability of the organism to fight bacterial infection, leading to severe septicemia, intoxication of the organism with the decay products of pathogens and its own tissues, septic shock and multi-organ failure [38]. A schematic representation of the mechanism is shown in Figure 2. For early and timely recognition of such a condition, and differential diagnostics, it is necessary to detect specific markers of the disease [39]. In connection with the dynamics of expression and their wide use in laboratory practice, the most interesting among the studied markers are the procalcitonin and C-reactive protein [40].

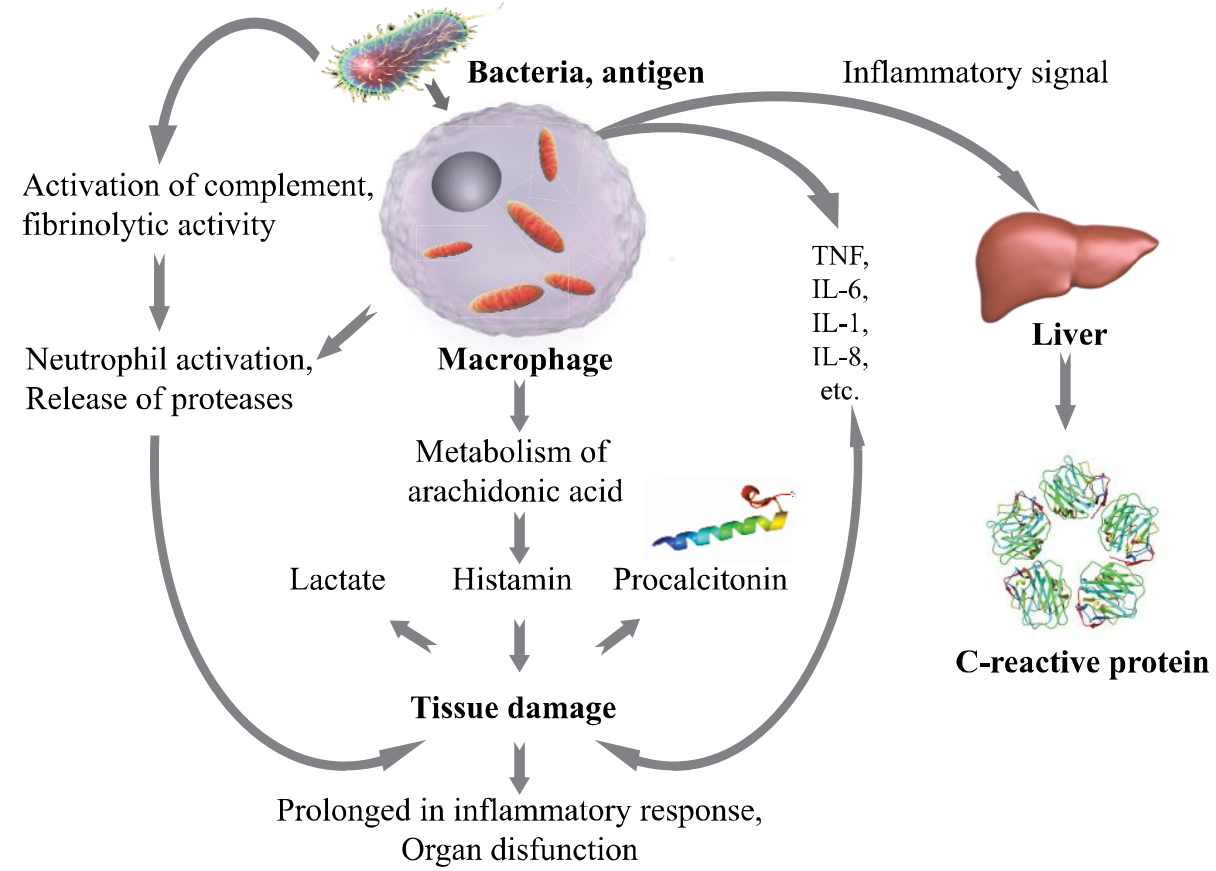

Figure 2. Mechanisms of sepsis, release of procalcitonin and C-reactive protein, on [41] with modifications

\subsection{Concentration of procalcitonin in blood during development of inflammatory process}

Procalcitonin is a $12.8 \mathrm{kDa}$ protein consisting of 116 amino acid residues that is a precursor to hormone calcitonin. Procalcitonin is synthesized in thyroid neuroendocrine cells and rarely enters the bloodstream in a normally functioning organism. However, during acute severe inflammatory processes, especially during generalization (sepsis), it can be synthesized in various organs and tissues [42].

A number of research groups demonstrated a direct dependence of the appearance of this marker in the blood on the time of manifestation of sepsis, its diagnostic and prognostic value [43]. For example, Miglietta et al. [44] showed that procalcitonin is found in high concentrations in the blood at the early stages of sepsis, and its content only decreases after intensive antibiotic therapy. The work of $\mathrm{Wu}$ et al. demonstrated the prognostic role of procalcitonin, since high levels of this marker were subsequently associated with the death of patients, while, in the surviving group, its content in the blood was lower [38]. However, the decisive factor in choosing this marker as an 
indicator of the presence of septic process due to bacterial infection is its important distinguishing feature-unlike other markers of inflammation, procalcitonin level never rises if the infection process has a viral etiology [45].

The dependence of procalcitonin concentration on the etiology of the disease (viral or bacterial infection) was confirmed in a number of studies, for instance, in patients with bacterial and viral meningitis [46]. In this work, Alkholi et al. showed that the marker level in cases of bacterial infection was, on average, $24.8 \mathrm{ng} / \mathrm{ml}$, while in cases of viral infection it was only $0.3 \mathrm{ng} / \mathrm{ml}$. In laboratory tests, the procalcitonin level in healthy people averaged $0.01 \mathrm{ng} / \mathrm{ml}$. In cases of viral and fungal infections, the procalcitonin level in the blood does not grow or increases to a maximum of $1 \mathrm{ng} / \mathrm{ml}$. Jacquot et al. [47] showed that, in a group of patients with an infectious process, the concentration of procalcitonin was significantly higher $(2.8 \mathrm{ng} / \mathrm{mL})$ than in a healthy group $(0.3 \mathrm{ng} / \mathrm{mL})$. If a systemic infection is suspected, the procalcitonin level of $0.5 \mathrm{ng} / \mathrm{ml}$ was considered a threshold level as early as in 2002 [48], and is still used as such [49]. At the present, a concentration of $0.4 \mathrm{ng} / \mathrm{mL}$ is chosen as a cut-off level to distinguish between positive and negative samples in laboratory diagnostics. This parameter is most often assessed in cases of suspected secondary infection, in order to understand its etiology in patients with immunodeficiency, including undergoing antibiotic therapy, after surgery, during sepsis monitoring, or suffering from multiple organ failure [38, 50].

After the initial appearance of endotoxins (fragments of the bacterial wall of bacteria), the level of procalcitonin in the blood sharply increases as early as $4 \mathrm{~h}$ later, reaches a peak in $6 \mathrm{~h}$, and begins to decrease after $24 \mathrm{~h}[51,52]$. This indicates an early, clinically significant and reliably detectable effect. To assess the efficacy of therapy for sepsis, the parameter of patient survival after 28 days is used [14]. This parameter is currently used in clinics around the world, in order to develop effective methods of treating patients with severe bacterial infections. Massive and lengthy clinical trials in the Netherlands, on the basis of studies in 15 hospitals, where the patients were treated for suspected bacterial infections, allowed for the summarizing of the use of procalcitonin and C-reactive protein as markers of the efficacy and duration of antibiotic therapy [53]. It was shown that, focusing on a change in the concentration of procalcitonin, it is possible to make the decision to stop taking antibiotics [50]. The final decision is made not only on the basis of laboratory data, but also on the medical history and general condition of the patient. In $42 \%$ of patients in the monitored group, antibiotics were canceled when the procalcitonin level was decreased by $20 \%$ of the initial level (measured at the beginning of the diagnosed disease), and in $52 \%$ when the level of this marker fell below $0.5 \mu \mathrm{g} / \mathrm{L}$, and in $6 \%$ of the patients when both conditions were satisfied.

\subsection{C-reactive protein as a marker of acute phase of inflammation}

C-reactive protein is an inflammatory cytokine (pentamer, molecular weight of about $120 \mathrm{kDa}$, Figure 3) [54] that is normally present in small amounts in the blood; it is able to bind with high affinity to fragments of dead cells or the plasma membrane, and to activate the complement system [55]. It is synthesized in hepatocytes and the detection of the marker protein is carried out in the blood serum. The concentration of C-reactive protein can increase in many inflammatory, autoimmune processes, as well as malignization (transformation of benign tumors to malignant tumors), and in $80 \%$ of cases in the postoperative period, therefore it is considered a marker of the acute phase of inflammation [56]. 


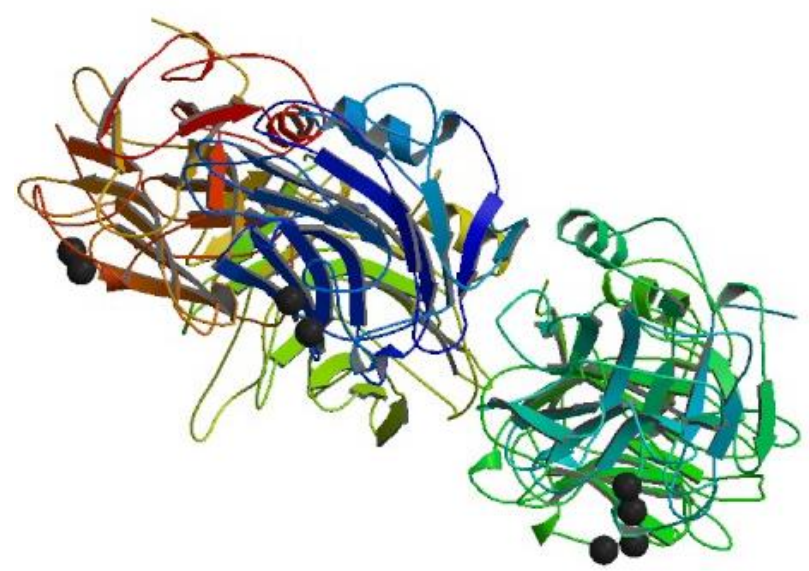

Figure 3. Structure of human C-reactive protein (PDB 1GNH)

The release of the C-reactive protein from hepatocytes is stimulated by interleukin-6. If the wound is infected, the kinetics change. The C-reactive protein behaves differently than procalcitonin - in cases of bacterial infection, the concentration of the protein begins to increase from between 6 and $12 \mathrm{~h}$, and reaches a peak only after 24-48 h [57]. Therefore, C-reactive protein can be used as an additional marker indicating the presence of a bacterial or viral infection [41]. Moreover, in the postoperative period, the level of procalcitonin most often increases in case of abdominal surgery, whereas the increase in the concentration of C-reactive protein does not depend on the type of intervention and may even exceed the usual levels detected in sepsis, which was observed in $18 \%$ of cases [58]. In laboratory, the reference values comprise $0-5 \mathrm{mg} / \mathrm{ml}$. In pediatrics, in cases of neonatal sepsis, a concentration above $5 \mu \mathrm{g} / \mathrm{ml}$ is an indicator of a critical state. At first, a highsensitivity assay (detection of C-reactive protein in the range of $0.08-80 \mu \mathrm{g} / \mathrm{ml}$ ) is carried out, and then the regular one, which allows for the detection of the marker in the range of $0.2-480 \mu \mathrm{g} / \mathrm{ml}$ (if the marker concentration is higher than $80 \mu \mathrm{g} / \mathrm{ml}$ ) [59]. The authors of other studies chose $1 \mu \mathrm{g} / \mathrm{ml}$ as the cut-off value [60]. The concentration of the marker which is detected in the range of $5-10 \mu \mathrm{g} / \mathrm{ml}$ is clinically significant for determining the presence of an inflammatory process, since its release into the blood begins between 6 and $12 \mathrm{~h}$ of the acute phase of the inflammatory process and reaches a peak after $48-60 \mathrm{~h}$.

Moreover, these markers can be used in diagnostics to assess the presence of inflammatory processes in the postoperative period [58], when the predominance of one or the other marker indicates either the SIRS syndrome or the secondary infection and the development of the infectious process. For example, after surgery, the level of interleukin-6 is the first to increase (2-3 h), then the level of procalcitonin increases $(6-12 \mathrm{~h})$, while the concentration of C-reactive protein increases only after 36-48 h [58].

Markers of inflammation (inflammatory proteins of the acute phase) are often mentioned in the studies of the pathogenesis of various diseases. In particular, an increase in the concentration of Creactive protein is observed in various pathological processes. Various diseases of connective tissue (collagenosis, arthritis, other joint diseases in the acute stage) lead to an increase in the level of this marker [61, 62].

\subsection{Other markers of inflammation and assessment of their levels in blood}

Analysis of the content of inflammation markers in the patient's blood is an important characteristic of antibiotic therapy, and an indicator of its efficacy. By the beginning of 2017, more than two hundred markers associated with sepsis were already known; among them, in addition to procalcitonin and C-reactive protein, there are such markers as presepsin, actin, alpha-1-acid glycoprotein (orosomucoid), and actin-binding proteins [63]. A 2010 survey by Pierrakos and Vincent [64] includes data on more than 3,000 studies and 178 markers. Among the sepsis markers described by the authors, there are interleukins $1 \beta, 2,4,6,8,10$, macrophage migration inhibitory factors (cytokines/chemokines), antithrombin, anticoagulant protein $\mathrm{C}$ (coagulation disorder factors), 
adrenomedullin, neopterin (markers of vasodilation and damage to the vascular endothelium) and others. With the development of diagnostic means for the purpose of timely diagnosis, other markers are also considered [65]. For instance, for diagnosis of neonatal sepsis, Dillenseger et al. [66] suggested using data on the content of procalcitonin with a semi-quantitative detection of interleukin 6, or data on the content of the C-reactive protein with a semi-quantitative or quantitative detection of interleukins 6 and 8. The use of antibiotics was started immediately in cases of persistent infection, or in a planned manner on the basis of semi-quantitative data on the content of IL -8 and PCT. If the concentrations of the markers (IL- 6 or CRPi, quantitative IL-8 or CRPi) were increasing, antibiotics were prescribed immediately, but this was an individual choice made by each of the clinics observing patients. In case of the development of an infectious lesion of the urinary system, the detection of other inflammatory markers (interleukins 17 and 22) was described [67]. To characterize the condition of patients with an acute inflammatory reaction, it is customary in medicine to use the concept of systemic inflammatory response syndrome (SIRS) [68]. For characterization of this syndrome, several biomarkers are usually taken into consideration, e.g., the C-reactive protein, procalcitonin, and interleukin-6.

The postoperative condition of patients also affects the ratio of blood cells and the release of various inflammatory mediators. Diagnostics, in some cases, is so complicated that a complex of analytical techniques are used, including serological, microbiological, histological studies, and interleukins 6 and 4 selected as markers; TNF-alpha and procalcitonin were also useful in the diagnostics of secondary joint infections after surgery [69]. Moreover, interleukin 6 itself is a regulator of the acute inflammatory phase and promotes the release of other inflammatory mediators and acute phase proteins. Interleukin 4 promotes the activation of $\mathrm{B}$ and $\mathrm{T}$ lymphocytes and differentiation of B lymphocytes into plasma cells. At the same time, the authors point to the need for further study of the problem, since these markers can be used for the purposes of routine analysis.

\section{Approaches to assessing efficacy of antibiotic therapy}

Despite the breadth of knowledge about existing and currently used drugs, it is often difficult to assess the efficacy of antibiotic therapy. This is due to a number of factors:

- The patient's condition does not always visually correspond to the severity of his appearance;

- Atypical course of the disease is possible;

- Patients who are on mechanical ventilation or unconscious (ventilator-associated pneumonia, sepsis) cannot describe their condition;

- Bacteriological plating of a biosample onto a nutrient medium takes a long time-several days, during which the patient's condition may deteriorate;

- The initial sensitivity of the pathogen to antibiotics may change;

- Over the course of therapy, the patient's condition may deteriorate, due to an exacerbation of existing chronic diseases;

- Unaccounted factors (incorrect dosing regimen, combination of an antibiotic with chemical compounds that change its activity - for example, taking tetracyclines with dairy products, calcium and iron salts).

To evaluate the efficacy of antibiotic therapy, it is necessary to concentrate on the main indicators - the concentration of the administered antibiotic (in blood, serum, plasma, urine, cerebrospinal fluid, if necessary) [70] - as well as the content of inflammatory markers (C-reactive protein as an acute phase protein and procalcitonin as an express marker of bacterial infections) [7173].

The concentration of an antibiotic in the blood needs to be determined, not only for the assessment of pharmacokinetics and pharmacodynamics, but also for the timely adjustment of the dose of the drug administered, especially in debilitated patients and in patients with multiple organ failure due to sepsis (with liver and kidney damage), when the toxic effect of the drug is very high. The latter case is accompanied by disturbances in the detoxification functions and changes in the duration of the drug's circulation in the blood, as well as its excretion from the body by the kidneys 
[14]. In patients in a critical condition, the efficacy of intravenous treatment with beta-lactam antibiotics is associated with the rapid achievement of effective concentration and penetration into various organs and tissues [15, 74, 75]. If a pathogen is resistant to beta-lactams, tetracycline preparations are often used. When administered parenterally, approximately $80 \%-90 \%$ of the antibiotic binds to plasma proteins, which ensures its prolonged circulation in the blood [76, 77]. The concentration of an antibiotic in the patient's blood is an indicator of its distribution and metabolism; it characterizes, to some extent, the response at the body level, but at the same time does not indicate whether the bacterial infection is sensitive to it. At the same time, the dynamics of concentration change are a more meaningful indicator than a single measurement.

Further laboratory indicators of the efficacy of antibiotic therapy are the content and dynamics of changes in the inflammatory markers procalcitonin and C-reactive protein in the blood [73]. This allows the assessment of the stage of the infection process, its etiology (viral, bacterial infection) and the presence of a secondary infection or superinfection.

Assessment of the level of procalcitonin at any stage of the disease requires the use of the prognostic property of the marker [78]. The work of Jhan et al. assessed the level of procalcitonin and analyzed its correlation with the results of microbiological analysis. The authors showed that the correlation coefficient for procalcitonin level and bacterial growth on a nutrient medium was 0.84 . The division of patients into groups on the basis of data on the content of procalcitonin was consistent with the previously described clinical trials of Gurol et al. [49] and was correlated with the current condition of patients undergoing antibiotic therapy. At the same time, the authors compared the procalcitonin concentration and the neutrophil-lymphocyte ratio (NLR) and, on the basis of obtained data, made conclusions about the presence or absence of correlation of laboratory indicators and the severity of the situation. According to the results of the analysis of the compared parameters, the following groups are identified as the border zones:

(i) healthy people $-\mathrm{PCT}, 0-0.05 \mathrm{ng} / \mathrm{ml}, \mathrm{NLR}, 4.19 \pm 4.36$;

(ii) local infection $-\mathrm{PCT}, 0.05-0.5 \mathrm{ng} / \mathrm{ml}, \mathrm{NLR}, 5.68 \pm 8.99$;

(iii) systemic infection (sepsis) $-\mathrm{PCT}, 0.5-2.0 \mathrm{ng} / \mathrm{ml}, \mathrm{NLR}, 11.78 \pm 11.04$;

(iv) systemic infection (sepsis) $-\mathrm{PCT}, 2.0-10.0$ ?) $\mathrm{ng} / \mathrm{ml}$, NLR, $13.16 \pm 4.38$;

(v) severe sepsis $-\mathrm{PCT},>10.0 \mathrm{ng} / \mathrm{ml}, \mathrm{NLR}, 16.87 \pm 9.55$.

Many authors conducting clinical trials note that, despite the high prognostic capacity of procalcitonin as a marker of bacterial infections, conducting such an analysis in all clinics for each patient is impossible because of its high cost [49]. Therefore, simple diagnostic test systems suitable for screening studies are under development. The guides for the management of patients with sepsis and septic shock recommend the analysis of procalcitonin levels in the blood [14].

The role of the C-reactive protein in the manifestation of infectious inflammatory process of a bacterial nature was reviewed in a 2017 publication by de Oliveira et al. [79]. They summarized data based on severe cases of bacterial infection (patients with immunodeficiency due to HIV or tuberculosis, who were undergoing permanent treatment with corticosteroid drugs). The level of serum C-reactive protein in the studies is not used to differentiate between viral and atypical bacterial infections [80], since it increases regardless of the type of pathogen. However, this parameter may indicate the presence of an inflammatory process in the acute phase, which is important in the absence of other evidence.

In terms of identifying inflammatory markers, the main factors determining their levels in the blood of patients are (i) the severity of the disease and its duration; (ii) the etiology of the disease (bacterial, viral or fungal infections, mixed infection, superinfection); (iii) administration of antibiotic or antiviral drugs, against the background of which the clinical picture can be blurred; (iv) the stage of antibiotic therapy (initial, final).

The above factors affect both the concentration of the detectable antigen in the blood and the final results of the detection, which can distort their interpretation. One of the criteria for the success of antibiotic therapy is the achievement of the level of antibiotic (minimum inhibitory concentration, MIC) in the patient's blood at which the pathogen is inactivated. However, not only the achievement of a given concentration is of importance, but also the pharmacokinetics of the specific drug used and the time required for its removal from the body. Therefore, maintaining the MIC at this level for as 
long as possible is the key to antibiotic therapy, if the pathogen is sensitive to this drug [81]. In a study by Grupper et al., antibiotic therapy efficacy was assessed by the level of growth of Pseudomonas aeruginosa colonies at various time intervals after the administration of clinically significant concentrations of beta-lactam antibiotics [82]. Among these antibiotics are meropenem, ceftolosan/tazobactam, and ceftazidime/tazobactam, which belong to the subclass of carbapenems (imipenems). The microbiological method was used to obtain the growth of bacteria in the cultural blood medium. The authors showed that the biggest growth was observed in $47 / 48 \mathrm{~h}(97.9 \%), 22 / 48$ $\mathrm{h}(45.8 \%)$, and the smallest in $11 / 48 \mathrm{~h}(22.9 \%)$, after the administration of the antibiotics. According to pharmacokinetics data, the concentration of meropenem, administered at a dose of $2 \mathrm{~g}$ three times every $8 \mathrm{~h}$ (standard scheme of intravenous beta-lactam administration) reached a peak of $40 \mu \mathrm{g} / \mathrm{ml}$ in blood plasma. Ceftolosan/tazobactam, administered at a dose of $3 \mathrm{~g}$ according to the same scheme, reached a peak of $150 \mu \mathrm{g} / \mathrm{ml}$, and ceftazidime/tazobactam, administered at a dose of $2.5 \mathrm{~g}$, reached 90 $\mu \mathrm{g} / \mathrm{ml}$ (based on the first, main component). Residual concentrations were 5, 8 and $10 \mu \mathrm{g} / \mathrm{ml}$, respectively. When studying bacterial growth periods, the authors showed that these are affected by lower levels of antibiotics $-0.5-8 \mu \mathrm{g} / \mathrm{ml}$ for meropenem, $0.5-4 \mu \mathrm{g} / \mathrm{ml}$ for ceftolosan, $2-8 \mu \mathrm{g} / \mathrm{ml}$ for ceftazidime. These are considered to be the minimal inhibitory concentrations. The study of the kinetics of reduction in the concentration of beta-lactam antibiotics, during the incubation of bacteria in a medium with these antibiotics, showed that the process is intensive, and in $12 \mathrm{~h}$ the concentration of antibiotics drops by $62.3 \%-90.2 \%$ of the administered dose. The authors showed that, in order to determine by the bacteriological method the efficacy of antibiotic therapy in patients receiving these antibiotics, it is necessary to take samples for plating right before the administration of the next dose of drugs.

Figure 4 shows changes in the concentrations of antibiotics of the beta-lactam group for various methods of administration reviewed by Grupper et al. [83]. The review demonstrated the advantage of long-term infusion (3-4 h) of antibiotics compared with short-term administration. This applies mainly to the therapy of infections caused by resistant microorganisms-Staphylococcus aureus, Enterococcus species, Escherichia coli, Klebsiella pneumoniae, Pseudomonas aeruginosa, and Acinetobacter baumannii. This method of drug administration, due to its long duration of infusion, allows for lower doses of the antibiotic, while maintaining its level above the minimum inhibitory concentration, which ensures a long bactericidal effect.

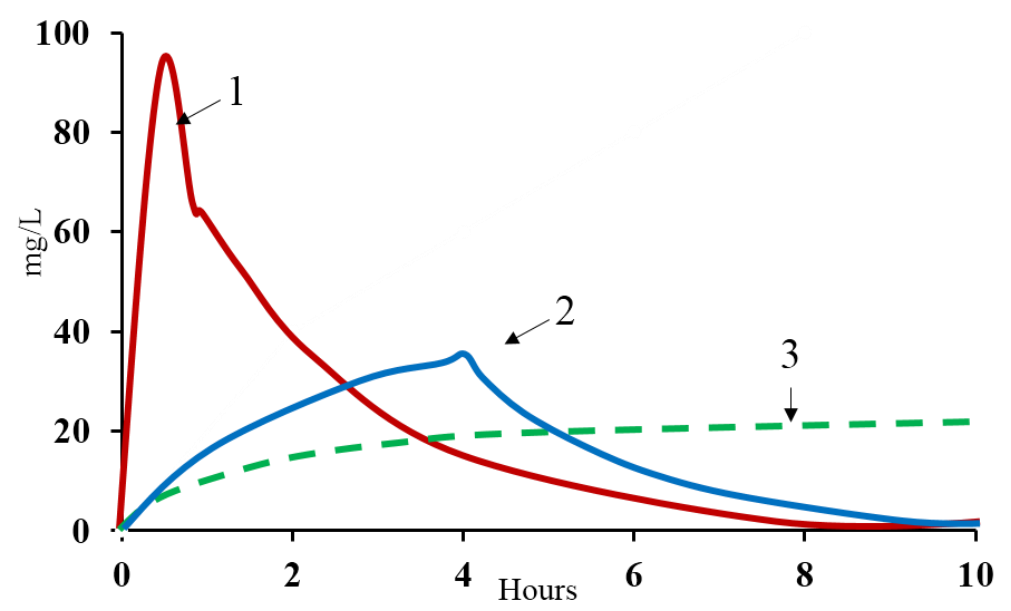

Figure 4. Changes in concentration of beta-lactams over time for various methods of infusion administration: traditional intermittent (curve 1), long-term (curve 2) and continuous administration (curve 3), on [83] with modifications

\section{Content of antibiotic drugs in the blood and methods of their detection}

\subsection{Potential of analytical methods used to assess content of antibiotics in the blood}


In addition to classical bacteriological methods of analysis, in which the efficacy of antibiotic therapy is determined by the amount and intensity of growth of colonies on a nutrient medium, there are a number of methods based on the direct detection of the concentration of antibiotic in the patient's blood (Table 3). These methods are based on the detection of the drug on the basis of the obtained concentration dependence, using a standard solution of the drug. They include mass spectrometry and high-performance liquid chromatography. As can be seen from Table 3, various chromatographic methods allow the determination of the concentration of beta-lactams, however, this requires careful sample preparation, which consists of removing blood cells, followed by precipitation of proteins and a ten-fold dilution of the sample [84]. In this section, we limited ourselves to beta-lactam antibiotics for an overall assessment of the situation, although there is a lot of work in this field.

Table 3. Detectable amounts of beta-lactam antibiotics in human blood plasma

\begin{tabular}{|c|c|c|c|c|}
\hline Antibiotic & $\begin{array}{l}\text { Detection } \\
\text { limit }\end{array}$ & $\begin{array}{c}\text { Range of } \\
\text { detectable } \\
\text { concentrations }\end{array}$ & Method & Ref. \\
\hline $\begin{array}{c}\text { Cefotaxime, } \\
\text { piperacillin } \backslash \text { tazobactam } \\
\text { and ciprofloxacin }\end{array}$ & $\begin{array}{c}\text { Minimum } \\
\text { inhibitory } \\
\text { concentration }>2 \\
\mu \mathrm{g} / \mathrm{ml}\end{array}$ & ND & $\begin{array}{l}\text { MALDI-TOF } \\
\text { mass } \\
\text { spectrometry }\end{array}$ & [85] \\
\hline $\begin{array}{l}\text { Piperacillin, ceftazidime, } \\
\text { flucloxacillin }\end{array}$ & $5 \mu \mathrm{g} / \mathrm{ml}$ & 5-200 $\mu \mathrm{g} / \mathrm{ml}$ & HPLC & [84] \\
\hline Meropenem & $2 \mu \mathrm{g} / \mathrm{ml}$ & $2-200 \mu \mathrm{g} / \mathrm{ml}$ & HPLC & [84] \\
\hline $\begin{array}{l}\text { Piperacillin } \backslash \text { tazobactam, } \\
\text { cefepime, meropenem, } \\
\text { ciprofloxacin }\end{array}$ & $0.15-1.50 \mu \mathrm{g} / \mathrm{ml}$ & ND & UPLC-MS/MS & [86] \\
\hline $\begin{array}{l}\text { Amoxicillin, ampicillin } \\
\text { phenoxymethylpenicillin, } \\
\text { piperacillin }\end{array}$ & $\begin{array}{l}0.57 \mu \mathrm{g} / \mathrm{ml} \\
0.83 \mu \mathrm{g} / \mathrm{ml} \\
0.09 \mu \mathrm{g} / \mathrm{ml} \\
0.42 \mu \mathrm{g} / \mathrm{ml}\end{array}$ & $\begin{array}{c}\text { LOQ - 51.05 } \\
\mu \mathrm{g} / \mathrm{ml} \\
\text { LOQ - 70,05 } \\
\mu \mathrm{g} / \mathrm{ml} \\
\text { LOQ - } 7.28 \\
\mu \mathrm{g} / \mathrm{ml} \\
\text { LOQ - 38.06 } \\
\mu \mathrm{g} / \mathrm{ml}\end{array}$ & $\begin{array}{l}\text { UPLC-MS/MS } \\
\text { analysis by } \\
\text { mixed-mode } \\
\text { solid phase } \\
\text { extraction }\end{array}$ & [87] \\
\hline $\begin{array}{c}\text { Piperacillin, } \\
\text { benzylpenicillin, } \\
\text { flucloxacillin, meropenem, } \\
\text { ertapenem, cephazolin and } \\
\text { ceftazidime }\end{array}$ & $\begin{array}{l}0.1 \mu \mathrm{g} / \mathrm{mL} \\
\text { flucloxacillin } \\
(0.25 \mu \mathrm{g} / \mathrm{mL})\end{array}$ & $\begin{array}{l}0.1-50 \text { and } 0.25- \\
25 \mu \mathrm{g} / \mathrm{ml}\end{array}$ & $\begin{array}{l}\text { Tandem mass } \\
\text { spectrometry }\end{array}$ & [88] \\
\hline
\end{tabular}

The values of the minimum inhibitory concentrations during antibiotic therapy with the main currently known tetracyclines are shown in Table 4. Gotfried et al. [89] studied the pharmacokinetics of tetracyclines and the achievement of working concentrations in blood plasma and alveolar fluid, during the treatment of bacterial infections of the respiratory tract. Since the half-life of tetracyclines, according to their pharmacokinetic parameters, comprises many hours (Table 5), the dosage of the drugs and the values of the minimum inhibitory concentrations differ from the data for beta-lactams. 
For instance, the dosage of tetracyclines is, on average, $50-100 \mathrm{mg}$, in contrast to beta-lactam antibiotics (1.5-3.5 g), but their residual concentration is detected in the blood even $24 \mathrm{~h}$ after administration, while the test for beta-lactams at this time point shows a negative result. The work of Xie et al. [90] on the detection of tigecycline by liquid chromatography with mass spectrometry, demonstrated the possibility of detection of this tetracycline group of antibiotics in a linear concentration range from 5 to $2,000 \mathrm{ng} / \mathrm{ml}$. For the "introduced-found" experiment, the concentrations of 10,100 , and $1600 \mathrm{ng} / \mathrm{ml}$ were used, which covers the concentration range that can be achieved by the drug in the blood. As an internal standard, the authors used tetracycline.

In the case of oral administration of tetracycline and doxycycline, Pascale et al. [91], at the very beginning of studies regarding the pharmacokinetics of tetracycline antibiotics showed that their concentration in bio-fluids reaches a peak $24-48 \mathrm{~h}$ after drug administration. For example, doxycycline reaches a concentration of $1.2 \mu \mathrm{g} / \mathrm{ml}$ and $8.1 \mu \mathrm{g} / \mathrm{ml}$ during the first $24 \mathrm{~h}$, then, during the next $24 \mathrm{~h}$, it rises to $3-10 \mu \mathrm{g} / \mathrm{ml}$. The concentration of doxycycline in the blood $48 \mathrm{~h}$ after administration is $2.1-2.9 \mu \mathrm{g} / \mathrm{ml}$ and tetracycline concentration is $-2.2-3.4 \mu \mathrm{g} / \mathrm{ml}$.

Table 4. Values of minimum inhibitory concentrations (MIC) for antibiotics of tetracycline group, with the example of resistant microorganisms

\begin{tabular}{|c|c|c|c|c|c|}
\hline \multirow{2}{*}{$\begin{array}{l}\text { Antibiotic } \\
\text { Tetracycline }\end{array}$} & \multicolumn{2}{|c|}{$\begin{array}{c}\mathrm{MIC}, \mu \mathrm{g} / \mathrm{ml} \\
\text { S. aureus, } \\
\text { wild type and resistant }\end{array}$} & \multicolumn{2}{|c|}{$\begin{array}{c}\text { MIC, } \mu \mathrm{g} / \mathrm{ml} \\
\text { S. pneumoniae, } \\
\text { wild type and resistant }\end{array}$} & \multirow{2}{*}{$\begin{array}{l}\text { Ref. } \\
\text { [92] }\end{array}$} \\
\hline & $<0.06$ & 32 & $<0.06$ & 32 & \\
\hline Omadacycline & 0.25 & 0.25 & $<0.06$ & $<0.06$ & [92] \\
\hline Tigecycline & 0.25 & 0.25 & $<0.06$ & $<0.06$ & [92] \\
\hline Minocycline & 0.25 & 2 & $<0.06$ & 8 & [92] \\
\hline
\end{tabular}

Table 5. Pharmacokinetic parameters for omadacycline and tigecycline in plasma, administered intravenously for $30 \mathrm{~min}$, at doses of $100 \mathrm{mg}$ and $50 \mathrm{mg}$, respectively [89]

\begin{tabular}{cccc}
\hline Drug & $\mathbf{C m a x}, \boldsymbol{\mu g} / \mathbf{m l}$ & $\mathbf{C} \mathbf{m i n}, \boldsymbol{\mu g} / \mathbf{m l}$ & Half-life, $\mathbf{h}$ \\
\hline Omadacycline & $2.12 \pm 0.68$ & $0.28 \pm 0.10$ & $16.0 \pm 3.5$ \\
Tigecycline & $0.98 \pm 0.21$ & $0.11 \pm 0.03$ & $11.4 \pm 2.6$ \\
\hline
\end{tabular}

\subsection{Storage of samples and calibration solutions for analytical purposes}

Some drugs may break down during the preparation of whole blood samples, as well as plasma or serum. In this case, it is necessary to take into account the rather low stability of beta-lactam antibiotics at environmental conditions. As shown in Table 6, the samples can be kept at room temperature for up to 2-4 h without loss of activity (hydrolysis of the beta-lactam cycle), and for up to $12 \mathrm{~h}$ in a refrigerator, and they are most stable under the conditions of deep freezing. In some cases, stock antibiotic solutions are acidified to ensure long-term stability. Thus, information on the stability of beta-lactam antibiotics in blood samples is necessary not only at the stage of collection and preparation of the samples (patient's blood), but also for the preparation of stock solutions of drugs for conducting short-term experiments. For better stability, stock solutions are prepared concentrated $(500-400 \mathrm{mg} / \mathrm{ml})$ and stored at $-80{ }^{\circ} \mathrm{C}$, while serum proteins are precipitated with acetonitrile comprising $0.1 \%$ formic acid, followed by dilution of the sample with acidified water [88].

Table 6. Stability of beta-lactam antibiotics in samples and blood fractions under various storage conditions (based on the study of stability over time)

\begin{tabular}{cccc}
\hline Sample & Storage regime & $\begin{array}{c}\text { Storage duration without loss } \\
\text { of antibiotic activity }\end{array}$ & Ref. \\
\hline Blood plasma & $-80^{\circ} \mathrm{C}$ & 6 mo. & {$[86]$} \\
Blood plasma & $-80^{\circ} \mathrm{C}$ & 9 mo. & {$[84]$} \\
Blood plasma & $-20^{\circ} \mathrm{C}$ & Not recommended & {$[86]$} \\
Blood plasma & $-20^{\circ} \mathrm{C}$ & 7 days & {$[86]$} \\
Blood serum & $\mathrm{RT}$ & $2 \mathrm{~h}$ & {$[86]$}
\end{tabular}




$\begin{array}{cccc}\text { Blood serum } & 2-8^{\circ} \mathrm{C} & 12 \mathrm{~h} & {[86]} \\ \text { Whole blood } & \mathrm{RT} & 4-6 \mathrm{~h} & {[84]} \\ \text { Whole blood, heparin tubes } & 2-8^{\circ} \mathrm{C} & 8 \mathrm{~h} & {[84]} \\ \text { Stock antibiotic solution } & & 4 \mathrm{~h} & {[93]} \\ \text { Stock antibiotic solution } & -20^{\circ} \mathrm{C} & 35 \mathrm{days} & {[87]} \\ \text { Stock antibiotic solution } & -80^{\circ} \mathrm{C} & 12 \mathrm{mo} . \\ \text { (methanol) } & -80^{\circ} \mathrm{C} & 12 \mathrm{mo} . & {[87]} \\ \text { Stock antibiotic solution } & & 9 \mathrm{mo} . & {[86]} \\ \text { (methanol) } & -80^{\circ} \mathrm{C} & 6 \mathrm{mo} . & \end{array}$

\section{Methods of detection of inflammatory markers in the blood}

Some data on the detection of the marker described in [59], indicating the working concentration ranges for the C-reactive protein and procalcitonin, are shown in Table 7. As can be seen from the table, detection of marker proteins is mainly carried out by immunochemical methods In recent years, due to the development of analytical methods based on the use of nanoparticles [94] and new receptor molecules (aptamers) [95] instead of antibodies, highly sensitive methods for determining specific inflammatory proteins were intensively developed. At the same time, classical immunochemical methods based on antigen-antibody interaction are still used in clinical practice, due to their high specificity and sensitivity of analysis, including the use of various markers.

Table 7. Detectable amounts of inflammatory markers in human blood

\begin{tabular}{|c|c|c|c|c|}
\hline $\begin{array}{l}\text { Inflammatory } \\
\text { marker, sample }\end{array}$ & $\begin{array}{l}\text { Detection } \\
\text { limit }\end{array}$ & $\begin{array}{c}\text { Range of } \\
\text { detectable } \\
\text { concentrations }\end{array}$ & Method & Ref. \\
\hline $\begin{array}{l}\text { C-reactive protein, } \\
\text { blood serum }\end{array}$ & $0.04 \mu \mathrm{g} / \mathrm{ml}$ & $0.18-8.51 \mu \mathrm{g} / \mathrm{ml}$ & Electrochemical method & [96] \\
\hline $\begin{array}{l}\text { C-reactive protein, } \\
\text { blood serum }\end{array}$ & $3.1 \mu \mathrm{g} / \mathrm{ml}$ & $3.125-25 \mu \mathrm{g} / \mathrm{ml}$ & Electrochemical method & {$[60]$} \\
\hline $\begin{array}{l}\text { C-reactive protein, } \\
\text { blood serum }\end{array}$ & $0.029 \mathrm{pg} / \mathrm{mL}$ & $\begin{array}{l}0.1 \mathrm{pg} / \mathrm{mL} \text { to } 100 \\
\mathrm{ng} / \mathrm{mL}\end{array}$ & $\begin{array}{l}\text { Electrochemical method, } \\
\text { aptasensor }\end{array}$ & [97] \\
\hline $\begin{array}{l}\text { C-reactive protein, } \\
\text { blood serum }\end{array}$ & $1 \mathrm{pM}$ & $1-100 \mathrm{pM}$ & $\begin{array}{c}\text { Electrochemical method, } \\
\text { aptasensor }\end{array}$ & [95] \\
\hline $\begin{array}{l}\text { C-reactive protein, } \\
\text { artificial sample }\end{array}$ & $10 \mathrm{nM}$ & $0-600 \mathrm{nM}$ & $\begin{array}{l}\text { Agglutination method using } \\
\text { treated magnetic particles }\end{array}$ & [98] \\
\hline $\begin{array}{l}\text { C-reactive protein, } \\
\text { blood }\end{array}$ & $5 \mu \mathrm{g} / \mathrm{ml}$ & $5-120 \mu \mathrm{g} / \mathrm{ml}$ & ICA & [94] \\
\hline $\begin{array}{l}\text { C-reactive protein, } \\
\text { blood, blood serum }\end{array}$ & $0.4 \mathrm{ng} / \mathrm{ml}$ & $0.3-81 \mathrm{ng} / \mathrm{ml}$ & ELISA & [99] \\
\hline $\begin{array}{l}\text { C-reactive protein, } \\
\text { blood serum }\end{array}$ & $10 \mathrm{ng} / \mathrm{ml}$ & $0.1-311.9 \mu \mathrm{g} / \mathrm{ml}$ & Immuno-MALDI-MS & [100] \\
\hline $\begin{array}{l}\text { Procalcitonin, blood } \\
\text { serum }\end{array}$ & $0.5 \mathrm{ng} / \mathrm{ml}$ & ND & Fluorescence immunoassay & [101] \\
\hline $\begin{array}{l}\text { Procalcitonin, blood } \\
\text { serum }\end{array}$ & $20 \mathrm{pg} / \mathrm{ml}$ & ND & ELISA, magnetic particles & [102] \\
\hline $\begin{array}{l}\text { Procalcitonin, blood } \\
\text { serum }\end{array}$ & $0.013 \mathrm{pg} / \mathrm{ml}$ & $\begin{array}{c}0.05 \mathrm{pg} / \mathrm{mL} \text { to } 80 \\
\mathrm{ng} / \mathrm{mL}\end{array}$ & $\begin{array}{l}\text { Immunosensor using } \\
\text { nanocomposite }\end{array}$ & [103] \\
\hline
\end{tabular}

\section{Summary comments}

A variety of approaches to antibiotic therapy, as well as an abundance of antibiotic drugs, still have not solved the problem of the efficacy of therapy. The development of resistant nosocomial forms of bacteria, atypical courses of disease, and factors of the microorganisms' aggression all lead to severe complications. In recent years, clinicians are increasingly inclined towards a personalized approach to treatment, where the patient's condition plays a key role. Written treatment standards 
are necessary, but they may not apply to all patients to the same degree. Study of the parameters that can be relied upon in the treatment of infection is of the greatest interest.

When determining the concentration of antibiotics in the blood (plasma, serum), it is necessary to take into account all the factors that may influence conclusions about their detection, including their structure (due to the instability of the beta-lactam ring, antibiotics of this group are rapidly inactivated), pharmacokinetic parameters of the particular drug, dosing regimen, the time from the moment of administration until the collection of a blood sample, and the conditions for the preparation and storage of samples. It is also necessary to take into account the time intervals during which the drug was administered, since its rapid elimination from the body indicates a decrease in the inhibitory concentration of the chosen drug.

An even greater reason for prescribing or replacing a drug is the dynamic of change and the initial content of inflammatory markers in the bloodstream. Taking into account several indicators (e.g., levels of C-reactive protein, procalcitonin, interleukins), it is possible to decide whether to prescribe antibiotics in therapeutic doses. However, there are different views on the prognostic role of inflammatory markers, since an increase in their content may occur as a reaction to surgery (procalcitonin [104]). An increase in the formation and release of the markers is also observed in acute infectious diseases (of respiratory, digestive, nervous and other systems), coronary syndrome and angina pectoris [105]. Acute, life-threatening conditions (sepsis, meningitis, stroke) [41], including the state of shock [106] and diseases accompanied by the formation of blood clots in the vessels [107], are also accompanied by an increase in the concentration of C-reactive proteins in the blood. With effective antibiotic therapy and the positive dynamics of the patient's condition, the concentration of the marker in the blood decreases. The use of information about the initial concentration of inflammation markers, and subsequent analytical data obtained during the treatment of acute bacterial infection, will allow the therapy to be corrected, the drug being administered to be replaced for a more effective one in a timely manner, and will help avoid complications in cases of regular monitoring. Among the proposed markers of inflammation, the most widely used in clinical practice are procalcitonin and C-reactive protein, the contents of which, in the patient's blood, can be used not only to understand the stage and intensity of the process, but also the efficacy of the therapy.

Author Contributions: Conceptualization, A.N.B. and A.V.Z.; methodology, A.N.B.; investigation, A.N.B and A.V.Z.; writing-original draft preparation, A.N.B.; writing-review and editing, A.N.B., A.V.Z. and B.B.D.; visualization, A.N.B. and A.V.Z.; supervision, B.B.D.; project administration, A.V.Z. and B.B.D; funding acquisition, A.V.Z. and B.B.D.

Funding: This work was financially supported by the Ministry of Science and Higher Education of Russian Federation, agreement № 14.613.21.0061, 17.07.2017; unique identification number of the project: RFMEFI61317X0061.

Acknowledgments: Authors are thankful to N.S. Komova for the support with figures.

Conflicts of Interest: The authors declare no conflict of interest.

\section{References}

1. Zhang D, Micek ST, Kollef MH Time to appropriate antibiotic therapy is an independent determinant of postinfection ICU and hospital lengths of stay in patients with sepsis. Crit Care Med 2015, 43(10):2133-2140.

2. Graetz TJ, Hotchkiss RS Preventing organ failure in sepsis - the search continues. Nature reviews. Nephrology 2017, 13(1):5-6.10.1038/nrneph.2016.171I.

3. Ferrer R, Martin-Loeches I, Phillips G, Osborn TM, Townsend S, Dellinger RP, et al Empiric antibiotic treatment reduces mortality in severe sepsis and septic shock from the first hour: results from a guidelinebased performance improvement program. Crit Care Med 2014, 42(8):17491755.10.1097/CCM.0000000000000330I. 
4. Gaieski DF, Mikkelsen ME, Band RA, Pines JM, Massone R, Furia FF, et al Impact of time to antibiotics on survival in patients with severe sepsis or septic shock in whom early goal-directed therapy was initiated in the emergency department. . Crit Care Med 2010, 38(4):1045-1053.

5. Abayasekara LM, Perera J, Chandrasekharan V, Gnanam VS, Udunuwara NA, Liyanage DS, et al Detection of bacterial pathogens from clinical specimens using conventional microbial culture and $16 \mathrm{~S}$ metagenomics: a comparative study. BMC Infect Dis 2017, 17(1):631.10.1186/s12879-017-2727-8I.

6. Maugeri G, Lychko I, Sobral R, Roque ACA Identification and antibiotic-susceptibility profiling of infectious bacterial agents: A review of current and future trends. Biotechnology journal 2019, 14(1):e1700750e1700750.10.1002/biot.201700750I.

7. Leekha S, Terrell CL, Edson RS General principles of antimicrobial therapy. Mayo Clinic proceedings 2011, 86(2):156-167.10.4065/mcp.2010.0639I.

8. Tekin E, Beppler C, White C, Mao Z, Savage VM, Yeh PJ Enhanced identification of synergistic and antagonistic emergent interactions among three or more drugs. Journal of The Royal Society Interface 2016, 13(119):20160332.doi:10.1098/rsif.2016.0332I.

9. Marx C, Mühlbauer V, Krebs P, Kuehn V Environmental risk assessment of antibiotics including synergistic and antagonistic combination effects. Science of The Total Environment 2015, 524-525(269279.https://doi.org/10.1016/j.scitotenv.2015.04.051I.

10. Frieri M, Kumar K, Boutin A Antibiotic resistance. Journal of Infection and Public Health 2017, 10(4):369378.https://doi.org/10.1016/j.jiph.2016.08.007I.

11. Coates ARM, Halls G, Hu Y Novel classes of antibiotics or more of the same? British Journal of Pharmacology 2011, 163(1):184-194.10.1111/j.1476-5381.2011.01250.xI.

12. Pien BC, Sundaram P, Raoof N, Costa SF, Mirrett S, Woods CW, et al The Clinical and Prognostic Importance of Positive Blood Cultures in Adults. The American Journal of Medicine 2010, 123(9):819828.https://doi.org/10.1016/j.amjmed.2010.03.021I.

13. Søgaard M, Nørgaard M, Dethlefsen C, Schønheyder HC Temporal Changes in the Incidence and 30-Day Mortality associated with Bacteremia in Hospitalized Patients from 1992 through 2006: A Population-based Cohort Study. Clinical Infectious Diseases 2011, 52(1):61-69.10.1093/cid/ciq069I.

14. Rhodes A, Evans LE, Alhazzani W, Levy MM, Antonelli M, Ferrer R, et al Surviving Sepsis Campaign: International Guidelines for Management of Sepsis and Septic Shock: 2016. Intensive Care Med 2017, 43(3):304-377.10.1007/s00134-017-4683-6I.

15. Lee JY, Kanga C-I, Koa J-H, Leea WJ, Seoka H-R, Parka GE, et al Clinical features and risk factors for development of breakthrough Gram-negative bacteremia during carbapenem therapy. Antimicrobial agents and chemotherapy 2016, 60(11):6673-6678.

16. Abdul-Aziz MH, Sulaiman H, Mat-Nor M-B, Rai V, Wong KK, Hasan MS, et al Beta-Lactam Infusion in Severe Sepsis (BLISS): a prospective, two-centre, open-labelled randomised controlled trial of continuous versus intermittent beta-lactam infusion in critically ill patients with severe sepsis. Intensive Care Medicine 2016, 42(10):1535-1545.10.1007/s00134-015-4188-0I.

17. Nimmich EB, Bookstaver PB, Kohn J, Justo JA, Hammer KL, Albrecht H, et al Development of Institutional Guidelines for Management of Gram-Negative Bloodstream Infections: Incorporating Local Evidence. Hospital Pharmacy 2017, 0(0):1-7.10.1177/0018578717720506I.

18. Kong K-F, Schneper L, Mathee K Beta-lactam Antibiotics: From Antibiosis to Resistance and Bacteriology. APMIS : acta pathologica, microbiologica, et immunologica Scandinavica 2010, 118(1):1-36.10.1111/j.16000463.2009.02563.xI. 
19. Dizbay M, ÖZGER HS, KARAŞAHIN Ö, KARAŞAHIN EF Treatment efficacy and superinfection rates in complicated urinary tract infections treated with ertapenem or piperacillin tazobactam. Turkish journal of medical sciences 2016, 46(6):1760-1764.

20. Rizk NA, Kanafani ZA, Tabaja HZ, Kanj SS Extended infusion of beta-lactam antibiotics: optimizing therapy in critically-ill patients in the era of antimicrobial resistance. Expert Review of Anti-infective Therapy 2017, 15(7):645-652.10.1080/14787210.2017.1348894I.

21. Blair JMA, Webber MA, Baylay AJ, Ogbolu DO, Piddock LJV Molecular mechanisms of antibiotic resistance. Nature Reviews Microbiology 2014, 13(42.10.1038/nrmicro3380I.

22. Liu Y-Y, Wang Y, Walsh TR, Yi L-X, Zhang R, Spencer J, et al Emergence of plasmid-mediated colistin resistance mechanism MCR-1 in animals and human beings in China: a microbiological and molecular biological study. The Lancet Infectious Diseases 2016, 16(2):161-168.https://doi.org/10.1016/S14733099(15)00424-7I.

23. Paterson DL, Harris PNA Colistin resistance: a major breach in our last line of defence. The Lancet Infectious Diseases 2016, 16(2):132-133.https://doi.org/10.1016/S1473-3099(15)00463-6I.

24. Lingzhi L, Haojie G, Dan G, Hongmei M, Yang L, Mengdie J, et al The role of two-component regulatory system in $\beta$-lactam antibiotics resistance. Microbiological Research 2018, 215(126129.https://doi.org/10.1016/j.micres.2018.07.005I.

25. Aliyu S, Smaldone A, Larson E Prevalence of multidrug-resistant gram-negative bacteria among nursing home residents: A systematic review and meta-analysis. American Journal of Infection Control 2017, 45(5):512518.https://doi.org/10.1016/j.ajic.2017.01.022I.

26. Deak D, Outterson K, Powers JH, Kesselheim AS Progress in the fight against multidrug-resistant bacteria? a review of u.s. food and drug administration-approved antibiotics, 2010-2015. Annals of Internal Medicine 2016, 165(5):363-372.10.7326/m16-0291I.

27. Cusini A, Herren D, Bütikofer L, Plüss-Suard C, Kronenberg A, Marschall J Intra-hospital differences in antibiotic use correlate with antimicrobial resistance rate in Escherichia coli and Klebsiella pneumoniae: a retrospective observational study. Antimicrobial Resistance \& Infection Control 2018, 7(1):89.10.1186/s13756018-0387-0I.

28. Geisinger E, Isberg RR Interplay between antibiotic resistance and virulence during disease promoted by multidrug-resistant bacteria. The Journal of Infectious Diseases 2017, 215(suppl_1):S9S17.10.1093/infdis/jiw402I.

29. Li X-Z, Li J. Antimicrobial Resistance in Stenotrophomonas maltophilia: Mechanisms and Clinical Implications. In: Antimicrobial Drug Resistance: Clinical and Epidemiological Aspects, Volume 2. Edited by Mayers DL, Sobel JD, Ouellette M, Kaye KS, Marchaim D. Cham: Springer International Publishing; 2017. pp. 937-958.

30. Ding Y, Teo J, Drautz-Moses DI, Schuster SC, Givskov M, Yang L The Acquisition of Resistance to Carbapenem and Macrolide-mediated Quorum Sensing Inhibition by Pseudomonas aeruginosa via a Novel Integrative and Conjugative Element ICETn43716385. bioRxiv 2017.10.1101/161497I.

31. Brooke JS, Di Bonaventura G, Berg G, Martinez J-L Editorial: A Multidisciplinary Look at Stenotrophomonas maltophilia: An Emerging Multi-Drug-Resistant Global Opportunistic Pathogen. Frontiers in Microbiology 2017, 8(1511.10.3389/fmicb.2017.01511I.

32. Mitchison D, Davies G The chemotherapy of tuberculosis: past, present and future [State of the art]. The International Journal of Tuberculosis and Lung Disease 2012, 16(6):724-732.10.5588/ijtld.12.0083I. 
33. Murri R, Fiori B, Spanu T, Mastrorosa I, Giovannenze F, Taccari F, et al Trimethoprim-sulfamethoxazole therapy for patients with carbapenemase-producing Klebsiella pneumoniae infections: retrospective single-center case series. Infection 2017, 45(2):209-213.10.1007/s15010-016-0968-xI.

34. Lagerbäck P, Khine WWT, Giske CG, Tängdén T Evaluation of antibacterial activities of colistin, rifampicin and meropenem combinations against NDM-1-producing Klebsiella pneumoniae in $24 \mathrm{~h}$ in vitro time-kill experiments. Journal of Antimicrobial Chemotherapy 2016, 71(8):2321-2325.10.1093/jac/dkw213I.

35. Drawz SM, Bonomo RA Three Decades of $\beta$-Lactamase Inhibitors. Clinical microbiology reviews 2010, 23(1):160-201.10.1128/cmr.00037-09I.

36. Campbell J, Singh AK, Santa Maria JP, Kim Y, Brown S, Swoboda JG, et al Synthetic lethal compound combinations reveal a fundamental connection between wall teichoic acid and peptidoglycan biosyntheses in Staphylococcus aureus. ACS Chemical Biology 2011, 6(1):106-116.10.1021/cb100269fI.

37. Khair O, Davies R, Devalia J Bacterial-induced release of inflammatory mediators by bronchial epithelial cells. European Respiratory Journal 1996, 9(9):1913-1922.

38. Wu Q, Nie J, Wu FX, Zou XL, Chen FY Prognostic value of high-sensitivity C-reactive protein, procalcitonin and pancreatic stone protein in pediatric sepsis. Med Sci Monit 2017, 23(1533-1539.

39. Tsalik EL, Jaggers LB, Glickman SW, Langley RJ, van Velkinburgh JC, Park LP, et al Discriminative value of inflammatory biomarkers for suspected sepsis. J Emerg Med 2012, 43(10.1016/j.jemermed.2011.05.072I.

40. Garnacho-Montero J, Huici-Moreno MJ, Gutiérrez-Pizarraya A, López I, Márquez-Vácaro JA, Macher H, et al Prognostic and diagnostic value of eosinopenia, C-reactive protein, procalcitonin, and circulating cellfree DNA in critically ill patients admitted with suspicion of sepsis. Critical Care 2014, 18(3):R116.10.1186/cc13908I.

41. Alqahtani MF, Marsillio LE, Rozenfeld RA A Review of Biomarkers and Physiomarkers in Pediatric Sepsis. Clinical Pediatric Emergency Medicine 2014, 15(2):177-184.https://doi.org/10.1016/j.cpem.2014.04.008I.

42. Gutiérrez-Gutiérrez B, Morales I, Pérez-Galera S, Fernández-Riejos P, Retamar P, de Cueto M, et al Predictive value of the kinetics of procalcitonin and C-reactive protein for early clinical stability in patients with bloodstream infections due to Gram-negative bacteria. Diagnostic Microbiology and Infectious Disease 2019, 93(1):63-68.https://doi.org/10.1016/j.diagmicrobio.2018.07.019I.

43. Wacker C, Prkno A, Brunkhorst FM, Schlattmann P Procalcitonin as a diagnostic marker for sepsis: a systematic review and meta-analysis. The Lancet Infectious Diseases 2013, 13(5):426435.https://doi.org/10.1016/S1473-3099(12)70323-7I.

44. Miglietta F, Faneschi ML, Lobreglio G, Palumbo C, Rizzo A, Cucurachi M, et al Procalcitonin, C-reactive protein and serum lactate dehydrogenase in the diagnosis of bacterial sepsis, SIRS and systemic candidiasis. Infez Med 2015, 23(3):230-237.

45. Schuetz P, Wirz Y, Sager R, Christ-Crain M, Stolz D, Tamm M, et al Effect of procalcitonin-guided antibiotic treatment on mortality in acute respiratory infections: a patient level meta-analysis. The Lancet Infectious Diseases 2017-2018.https://doi.org/10.1016/S1473-3099(17)30592-3I.

46. Alkholi UM, Abd Al-monem N, Abd El-Azim AA, Sultan MH Serum Procalcitonin in Viral and Bacterial Meningitis. Journal of Global Infectious Diseases 2011, 3(1):14-18.10.4103/0974-777x.77290I.

47. Jacquot A, Labaune JM, Baum TP, Putet G, Picaud JC Rapid quantitative procalcitonin measurement to diagnose nosocomial infections in newborn infants. Archives of Disease in Childhood - Fetal and Neonatal Edition 2009, 94(5):F345.10.1136/adc.2008.155754I.

48. Hausfater P, Garric S, Ayed SB, Rosenheim M, Bernard M, Riou B Usefulness of procalcitonin as a marker of systemic infection in emergency department patients: a prospective study. Clin Infect Dis 2002, 34(7):895901.10.1086/339198I. 
49. Gürol G, Ciftci I, Agah Terzi H, Atasoy A, Ozbek A, Koroglu M. Are there standardized cutoff values for neutrophil-lymphocyte ratios in bacteremia or sepsis? In: J Microbiol Biotechnol; 2015. pp. 521-525.

50. Trasy D, Tanczos K, Nemeth M, Hankovszky P, Lovas A, Mikor A, et al Early procalcitonin kinetics and appropriateness of empirical antimicrobial therapy in critically ill patients: A prospective observational study. J Crit Care 2016, 34(50-55.10.1016/j.jcrc.2016.04.007I.

51. Dandona P, Nix D, Wilson MF, Aljada A, Love J, Assicot M, et al Procalcitonin increase after endotoxin injection in normal subjects. J Clin Endocrinol Metab 1994, 79(6):1605-1608.10.1210/jcem.79.6.7989463I.

52. Hatherill M, Tibby SM, Sykes K, Turner C, Murdoch IA Diagnostic markers of infection: comparison of procalcitonin with C reactive protein and leucocyte count. Arch Dis Child 1999, 81(5):417-421.

53. de Jong E, van Oers JA, Beishuizen A, Vos P, Vermeijden WJ, Haas LE, et al Efficacy and safety of procalcitonin guidance in reducing the duration of antibiotic treatment in critically ill patients: a randomised, controlled, open-label trial. The Lancet Infectious Diseases 2016, 16(7):819827.https://doi.org/10.1016/S1473-3099(16)00053-0I.

54. Shrive AK, Cheetham GM, Holden D, Myles DA, Turnell WG, Volanakis JE, et al Three dimensional structure of human C-reactive protein. Nat Struct Biol 1996, 3(4):346-354.

55. Kop WJ, Weinstein AA. C-Reactive Protein. In: Encyclopedia of Stress (Second Edition). Edited by Editor-inChief: George Fink. Associate Editors:Bruce McEwen ERdK, Robert Rubin, George Chrousos, Andrew Steptoe, Noel Rose, Ian Craig, Giora Feuerstein; 2007. pp. 653-658.

56. Pepys MB, Hirschfield GM C-reactive protein: a critical update. The Journal of Clinical Investigation 2003, 111(12):1805-1812.10.1172/jci18921I.

57. Mary R, Veinberg F, Couderc R Acute meningitidis, acute phase proteins and procalcitonin. Ann Biol Clin (Paris) 2003, 61(2):127-137.

58. Sariego-Jamardo A, Rey C, Medina A, Mayordomo-Colunga J, Concha-Torre A, Prieto B, et al C-reactive protein, procalcitonin and interleukin-6 kinetics in pediatric postoperative patients. Journal of Critical Care 2017, 41(Supplement C):119-123.https://doi.org/10.1016/j.jcrc.2017.05.009I.

59. Vashist SK, Venkatesh AG, Marion Schneider E, Beaudoin C, Luppa PB, Luong JHT Bioanalytical advances in assays for C-reactive protein. Biotechnology Advances 2016, 34(3):272290.https://doi.org/10.1016/j.biotechadv.2015.12.010I.

60. Songjaroen T, Feeny RM, Mensack MM, Laiwattanapaisal W, Henry CS Label-free detection of C-reactive protein using an electrochemical DNA immunoassay. Sensing and Bio-Sensing Research 2016, 8(Supplement C):14-19.https://doi.org/10.1016/j.sbsr.2016.03.003I.

61. Rhodes B, Furnrohr BG, Vyse TJ C-reactive protein in rheumatology: biology and genetics. Nat Rev Rheumatol 2011, 7(5):282-289.10.1038/nrrheum.2011.37I.

62. Kim K-W, Kim B-M, Moon H-W, Lee S-H, Kim H-R Role of C-reactive protein in osteoclastogenesis in rheumatoid arthritis. Arthritis Research \& Therapy 2015, 17(1):41.10.1186/s13075-015-0563-zI.

63. Kustán P, Horváth-Szalai Z, Mühl D Nonconventional Markers of Sepsis. EJIFCC 2017, 28(2):122-133.

64. Pierrakos C, Vincent J-L Sepsis biomarkers: a review. Crit Care 2010, 14(1):R15.10.1186/cc8872I.

65. Kuroda K, Wake H, Mori S, Hinotsu S, Nishibori M, Morimatsu H Decrease in histidine-rich glycoprotein as a novel biomarker to predict sepsis among Systemic Inflammatory Response Syndrome. Critical Care Medicine 2018, 46(4):570-576.10.1097/ccm.0000000000002947I.

66. Dillenseger L, Langlet C, Iacobelli S, Lavaux T, Ratomponirina C, Labenne M, et al Early Inflammatory Markers for the Diagnosis of Late-Onset Sepsis in Neonates: The Nosodiag Study. Frontiers in Pediatrics 2018, 6(346).10.3389/fped.2018.00346I. 
67. Ahmadikia K, Kordbacheh P, Shadpour P, Nami S, Sarrafnejad A, Mahmoodi M, et al Increased urine Interleukin-17 and Interleukin-22 levels in patients with candidal urinary tract infection. Iranian journal of kidney diseases 2018, 12(1):33.

68. Horeczko T, Green JP, Panacek EA Epidemiology of the Systemic Inflammatory Response Syndrome (SIRS) in the Emergency Department. Western Journal of Emergency Medicine 2014, 15(3).10.5811/westjem.2013.9.18064I.

69. Rondon AJ, Tan TL, Parvizi J. Serological Markers of Infection in the Infected Total Knee Arthroplasty. In: The Infected Total Knee Arthroplasty: Prevention, Diagnosis, and Treatment. Edited by Rodríguez-Merchán EC, Oussedik S. Cham: Springer International Publishing; 2018. pp. 71-78.

70. Berlina AN, Bartosh AV, Zherdev AV, Xu C, Dzantiev BB Development of Immunochromatographic assay for determination of tetracycline in human serum. Antibiotics (Basel, Switzerland) 2018, 7(4):99.10.3390/antibiotics7040099I.

71. Plebani M, Fabbri Leonardo M. Procalcitonin-guided antibiotic therapy: a potentially effective and efficient strategy. In: Clinical Chemistry and Laboratory Medicine (CCLM); 2015. pp. 519.

72. Schuetz P, Bolliger R, Merker M, Christ-Crain M, Stolz D, Tamm M, et al Procalcitonin-guided antibiotic therapy algorithms for different types of acute respiratory infections based on previous trials. Expert Review of Anti-infective Therapy 2018, 16(7):555-564.10.1080/14787210.2018.1496331I.

73. Meili M, Kutz A, Briel M, Christ-Crain M, Bucher HC, Mueller B, et al Infection biomarkers in primary care patients with acute respiratory tract infections-comparison of Procalcitonin and C-reactive protein. BMC Pulmonary Medicine 2016, 16(1):43.10.1186/s12890-016-0206-4I.

74. Crandon JL, Bulik CC, Kuti JL, Nicolau DP Clinical pharmacodynamics of cefepime in patients infected with Pseudomonas aeruginosa. Antimicrob Agents Chemother 2010, 54(3):1111-1116.10.1128/AAC.01183-09I.

75. Roberts JA, Abdul-Aziz MH, Davis JS, Dulhunty JM, Cotta MO, Myburgh J, et al Continuous versus Intermittent beta-Lactam Infusion in Severe Sepsis. A Meta-analysis of Individual Patient Data from Randomized Trials. Am J Respir Crit Care Med 2016, 194(6):681-691.10.1164/rccm.201601-0024OCI.

76. Alfouzan WA, Noel AR, Bowker KE, Attwood MLG, Tomaselli SG, MacGowan AP Pharmacodynamics of minocycline against Acinetobacter baumannii Studied in a Pharmacokinetic Model of Infection. International Journal of Antimicrobial Agents 2017.https://doi.org/10.1016/j.ijantimicag.2017.06.026I.

77. Chen A, Smith KP, Whitfield BA, Zucchi PC, Lasco TM, Bias TE, et al Activity of minocycline against Klebsiella pneumoniae carbapenemase (KPC)-producing Enterobacteriaceae clinical isolates, with comparison to doxycycline and tigecycline. Diagnostic Microbiology and Infectious Disease 2017, 88(4):365367.https://doi.org/10.1016/j.diagmicrobio.2017.05.004I.

78. Jhan J, Huang Y, Shih C, Yang J, Lin Y, Lin S-J, et al Procalcitonin levels to predict bacterial infection in Surgical Intensive Care Unit patients. Formosan Journal of Surgery 2017, 50(4):135-141.10.4103/fjs.fjs_54_17I.

79. de Oliveira VM, Moraes RB, Stein AT, Wendland EM Accuracy of C - Reactive protein as a bacterial infection marker in critically immunosuppressed patients: A systematic review and meta-analysis. Journal of Critical Care 2017, 42(Supplement C):129-137.https://doi.org/10.1016/j.jcrc.2017.07.025I.

80. Durán A, González A, Delgado L, Mosquera J, Valero N Serum level of C-reactive protein is not a parameter to determine the difference between viral and atypical bacterial infections. Journal of Medical Virology 2016, 88(2):351-355.10.1002/jmv.24341I.

81. Zheng W, Sun $\mathrm{W}$, Simeonov A Drug repurposing screens and synergistic drug-combinations for infectious diseases. British Journal of Pharmacology 2018, 175(2):181-191.10.1111/bph.13895I. 
82. Grupper M, Nicolau DP, Aslanzadeh J, Tanner LK, Kuti JL Effects of Clinically Meaningful Concentrations of Anti-Pseudomonal $\beta$-Lactams on Time to Detection and Organism Growth in Blood Culture Bottles. , . Journal of Clinical Microbiology 2017, JCM-01241(17.

83. Grupper M, Kuti JL, Nicolau DP Continuous and Prolonged Intravenous $\beta$-Lactam Dosing: Implications for the Clinical Laboratory. Clinical microbiology reviews 2016, 29(4):759-772.

84. Pinder N, Brenner T, Swoboda S, Weigand MA, Hoppe-Tichy T Therapeutic drug monitoring of betalactam antibiotics - Influence of sample stability on the analysis of piperacillin, meropenem, ceftazidime and flucloxacillin by HPLC-UV. Journal of pharmaceutical and biomedical analysis 2017, 143(Supplement C):8693.https://doi.org/10.1016/j.jpba.2017.05.037I.

85. Jung JS, Hamacher C, Gross B, Sparbier K, Lange C, Kostrzewa M, et al Evaluation of a semi-quantitative MALDI-TOF MS method for rapid antimicrobial susceptibility testing of positive blood cultures. Journal of Clinical Microbiology 2016, JCM-01131(16.

86. Zander J, Maier B, Zoller M, Döbbeler G, Frey L, Teupser D, et al. Effects of biobanking conditions on six antibiotic substances in human serum assessed by a novel evaluation protocol. In: Clinical Chemistry and Laboratory Medicine (CCLM); 2016. pp. 265-274.

87. Colin P, De Bock L, T'Jollyn H, Boussery K, Van Bocxlaer J Development and validation of a fast and uniform approach to quantify $\beta$-lactam antibiotics in human plasma by solid phase extraction-liquid chromatography-electrospray-tandem mass spectrometry. Talanta 2013, 103(Supplement C):285293.https://doi.org/10.1016/j.talanta.2012.10.046I.

88. Sime FB, Roberts MS, Roberts JA, Robertson TA Simultaneous determination of seven $\beta$-lactam antibiotics in human plasma for therapeutic drug monitoring and pharmacokinetic studies. Journal of Chromatography B 2014, 960(Supplement C):134-144.https://doi.org/10.1016/j.jchromb.2014.04.029I.

89. Gotfried MH, Horn K, Garrity-Ryan L, Villano S, Tzanis E, Chitra S, et al Comparison of Omadacycline and Tigecycline Pharmacokinetics in the Plasma, Epithelial Lining Fluid, and Alveolar Cells of Healthy Adult Subjects. . Antimicrobial agents and chemotherapy 2017, 61(9):e01135-01117.

90. Xie J, Wang T, Wang X, Cheng X, Dong H, Wang Y, et al Quantitative analysis and pharmacokinetics study of tigecycline in human serum using a validated sensitive liquid chromatography with tandem mass spectrometry method. Journal of separation science 2014, 37(12):1396-1403.10.1002/jssc.201400152I.

91. Pascale D, Gordon J, Lamster I, Mann P, Seiger M, Arndt W Concentration of doxycycline in human gingival fluid. Journal of Clinical Periodontology 1986, 13(9):841-844.10.1111/j.1600-051X.1986.tb02240.xI.

92. Honeyman L, Ismail M, Nelson M, Bhatia B, Bowser TE, Chen J, ... \& , et al Structure-activity relationship of the aminomethylcyclines and the discovery of omadacycline. Antimicrobial agents and chemotherapy 2015, AAC-01536(

93. Carlier M, De Waele Jan J, Verstraete Alain G, Stove V. Exploration of the pre-analytical stability of $\beta$ lactam antibiotics in plasma and blood - implications for therapeutic drug monitoring and pharmacokinetic studies. In: Clinical Chemistry and Laboratory Medicine (CCLM); 2015. pp. e227.

94. Soejima M, Koda Y Evaluation of point-of-care testing of C-reactive protein in forensic autopsy cases. Forensic Science International 2014, 237(Supplement C):27-29.https://doi.org/10.1016/j.forsciint.2014.01.008I.

95. Jarczewska M, Rębiś J, Górski Ł, Malinowska E Development of DNA aptamer-based sensor for electrochemical detection of C-reactive protein. Talanta 2018, 189(4554.https://doi.org/10.1016/j.talanta.2018.06.035I.

96. Kumar D, Prasad BB Multiwalled carbon nanotubes embedded molecularly imprinted polymer-modified screen printed carbon electrode for the quantitative analysis of C-reactive protein. Sensors and Actuators B: Chemical 2012, 171-172(Supplement C):1141-1150.https://doi.org/10.1016/j.snb.2012.06.053I. 
97. Wang Z, Dong P, Sun Z, Sun C, Bu H, Han J, et al NH2-Ni-MOF electrocatalysts with tunable size/morphology for ultrasensitive C-reactive protein detection via an aptamer binding induced DNA walker-antibody sandwich assay. Journal of Materials Chemistry B 2018, 6(16):24262431.10.1039/c8tb00373dI.

98. Iwasaki S, Kawasaki H, Iwasaki Y Label-Free Specific Detection and Collection of C-Reactive Protein Using Zwitterionic Phosphorylcholine-Polymer-Protected Magnetic Nanoparticles. Langmuir 2019, 35(5):17491755.10.1021/acs.langmuir.8b01007I.

99. Vashist SK, Czilwik G, van Oordt T, von Stetten F, Zengerle R, Marion Schneider E, et al One-step kineticsbased immunoassay for the highly sensitive detection of C-reactive protein in less than 30min. Anal Biochem 2014, 456(Supplement C):32-37.https://doi.org/10.1016/j.ab.2014.04.004I.

100. Meyer K, Ueland PM Targeted Quantification of C-Reactive Protein and Cystatin C and Its Variants by Immuno-MALDI-MS. Analytical Chemistry 2014, 86(12):5807-5814.10.1021/ac500704yI.

101. Huang Z, Chen Y, Sun F, Lei L, Yu, Q., Wu S Values of combined detection of bronchoalveolar lavage fluid endotoxin and serum procalcitonin levels for the rapid diagnosis of early methicillinresistant Staphylococcus aureus-caused ventilator-associated pneumonia. Biomedical Research 2017, 28(11).

102. Liao T, Yuan F, Yu H, Li Z An ultrasensitive ELISA method for the detection of procalcitonin based on magnetic beads and enzyme-antibody labeled gold nanoparticles. Analytical Methods 2016, 8(7):15771585.10.1039/c5ay03298aI.

103. Fang Y, Hu Q, Yu X, Wang L Ultrasensitive electrochemical immunosensor for procalcitonin with signal enhancement based on zinc nanoparticles functionalized ordered mesoporous carbon-silica nanocomposites. Sensors and Actuators B: Chemical 2018, 258(Supplement C):238245.https://doi.org/10.1016/j.snb.2017.11.062I.

104. Cui P, Fang X Pathogenesis of infection in surgical patients. Curr Opin Crit Care 2015, 21(4):343350.10.1097/MCC.0000000000000227I.

105. Ridker PM From C-Reactive Protein to Interleukin-6 to Interleukin-1. Moving Upstream To Identify Novel Targets for Atheroprotection 2016, 118(1):145-156.10.1161/circresaha.115.306656I.

106. Kyr M, Fedora M, Elbl L, Kugan N, Michalek J Modeling effect of the septic condition and trauma on Creactive protein levels in children with sepsis: a retrospective study. Critical Care 2007, 11(3):R70R70.10.1186/cc5955I.

107. Bisoendial RJ, Boekholdt SM, Vergeer M, Stroes ES, Kastelein JJ C-reactive protein is a mediator of cardiovascular disease. Eur Heart J 2010, 31(17):2087-2091.10.1093/eurheartj/ehq238I. 